\title{
ANALYSIS OF FIELDWORK METHODOLOGY IN ANTHROPOGEOGRAPHIC WORKS OF JOVAN CVIJIĆ
}

\author{
Ljiljana Živković*1, Slavoljub Jovanović* ${ }^{*}$ Ivana Đorđević* \\ * University of Belgrade - Faculty of Geography, Belgrade
}

\begin{abstract}
Interpreting the extensive and varied bibliography of Jovan Cvijić, largely in foreign languages, which apart from the text includes geographic and ethnographic map of the Balkan Peninsula, atlases, notes and drawings, it is concluded that his scientific work was versatile and complex. Cvijićs perception of space, the use of didactic principles, methods and forms of work can be categorized as actual and modern even in the present time. He was the first among the Balkan geographers who simultaneously interpreted natural, historical, sociological, ethnographic and ethno-psychological phenomena and processes. Cvijić pointed to the relationship between the geographic environment and human communities, civilizations and historical events, constantly examining their mutual conditionality. Numerous research trips in almost all regions of the Balkan Peninsula led to his interest in the culture and customs of the people. He noted that in the Balkans, there are different people by origin, religion and mentality. The result of the field research is certainly one of Cvijićs most important work - "Anthropogeographical problems of the Balkan Peninsula". His scientific approach has given an outstanding contribution to methodological development of geography.
\end{abstract}

Keywords: field research, Jovan Cvijić, Balkan Peninsula.

\section{Introduction}

Eminent and internationally recognized scientist Jovan Cvijić had a chance to feel the effects of many ethno-psychological environments because he was born in a relatively urban area (the small town of Loznica), but occasionally

1 Corresponding author: Lj. Živković, University of Belgrade - Faculty of Geography, Belgrade; e-mail: ljzivkovic@gef.bg.ac.rs 
lived in rural areas as well. He pointed out that the immense support was given to him within the family, mostly by his mother, who wanted him to be well educated. With his uncle, he traveled through the villages in the surrounding area, and as he later recalled, that led to the finest observations about the psychological characteristics of bright people, farmers, self-taught and all those whom his uncle knew (Stanković, 2016).

During his education, first in Loznica, then in Šabac in high school and later in Belgrade, he had the support of the teachers to acquire knowledge through reading and field research. High school principal Djuro Kozarac carried out excursions with the students to show them the characteristics of the flora. "I started to make my herbarium and a desire to extend the herbarium led me to make excursions in a large part of the Podrinje district" (Stanković, 2016). When he moved to continue his education in Belgrade, in addition to botany taught by Kozarac there were excellent teachers of zoology and in anatomy and human physiology of man. However, after graduating from high school, the future scientist faced a seemingly insurmountable obstacle - Municipality of Loznica refused to grant him a scholarship for his planned studies of medicine abroad. Not knowing how he could solve this problem, he addressed his secondary school professor Vladimir Karić who advised him to enroll the study of geography at the Belgrade Great School (Stanković, 2016).

Multidisciplinary research of the Balkan Peninsula in the past dealt with scientists because of its geographical position, multiethnic, multilingual and multicultural mosaic (Šabić, Pavlović, Vujadinović, 2016). The first important field research carried out at the very beginning of his career was exploring the karst landscapes of eastern Serbia. Observing the karst in the area of Kučaj Mt. and Prekonoška cave, Cvijić decided to to expand his research to other areas. In later works he pointed out how geographic environment affects health, behavior and psychology of the inhabitants of areas that he studied. Especially important are his studies of migrations (he used the expression "metanastasic movements") in which a lot of attention was directed to the ethno-psychological characteristics.

There was also the Seminar in which Cvijić as a teacher gathered interested students and directed them towards the scientific work. Constructive discussions, developing critical thinking, introduction to the theoretical concepts of many sciences, procurement of literature, magazines, his mentoring work and methodological instructions turned the Seminar in the center of gathering of students, professors and scientists (Prelić, 2014). Of great importance was the field and teamwork that developed in the seminar. 


\section{Methodological contribution of Jovan Cvijić to contemporary field research}

One of the pioneers of ethno-psychological research is certainly Jovan Cvijić, who spent almost the entire lifetime in the field among the people with whom he spoke and whose environment he observed and studied. As a result of all the efforts, for the first time in 1911, he wrote the Guidelines for the research of settlements and psychological characteristics, which are complemented in 1922. Posthumously in 1931 his book Psychological characteristics of the southern Slavs was published, becoming an unavoidable literature not only for the followers of Cvijić anthropogeographical school, but also as a manual for field work. Cvijić developed a methodological plan of field research in the form of guidelines for the study of social phenomena. That was an organized and systematic collection of scientific material about the situation in the Balkans. In order to direct the scientific work of his young associates, he published five detailed guidelines for field studies of population and settlements: "Guidelines for the study of villages in Serbia and other Serbian lands", Belgrade, 1896, "Guidelines for the study of villages in Bosnia and Herzegovina", Sarajevo, 1898, "Guidelines for the study of villages in Old Serbia and Macedonia", Belgrade, 1898, "Guidelines for the study of settlements and psychological characteristics", Belgrade, 1911 and "Guidelines for the study of the origin the population and psychological characteristics", Novi Sad.

Questions addressed by Jovan Cvijić in the first Guidelines can be classified into seven groups: (1) the position of the village; (2) type of villages; (3) house, yard and garden; (4) barns (5) folk stories and interpretations of the names of villages, hamlets and their areas; (6) origin of population, origin of villages; (7) occupation of the population. The final Guidelines put the emphasis on the origin and psychological attributes of the village and the town population. With these Guidelines Cvijic raised questions in the context of human geography related to the study of the psychological characteristics of the people of the region; the study of the psychological characteristics of natives and immigrants; the study of the psychological characteristics of the most important and most interesting families and typical characteristics of particular regions. Some regions have a written record of the immigration population (settling), historical sources, obituaries and municipal registers, but this is especially recommended for investigators to study, adding that in addition to these written sources is an important principle to "go from house to house" to find out the origin of each family.

In the first book Settlements from 1902, Cvijić published his work under the title Anthropogeographical problems of the Balkan Peninsula, where he 
introduced the methodology of research and expressed the main ideas and results obtained in the former surveys of Balkan regions and countries. At the beginning of the "Guidelines for the examination of the origin of population and psychological characteristics", Matica Srpska, 1922 he writes that the Guidelines are intended for the examination of the rural and town population, especially in Slavonia, Srem, Bačka, Banat and Baranja and northwestern parts of the Balkan Peninsula. The introductory part also points out that it is necessary that the population of all religions and nationalities is included. In the introduction to the Guidelines there are significant remarks about the need that the examiner knows the literature about the area and the population examined and to review the church and the local archives in order to learn about the area that is being studied. It shows that he already knew the importance of adequate preparation for fieldwork, exploring historical and general socio-cultural characteristics of the environment that is being observed. The aim of this is easier orientation and identification of the relevant facts that are of great benefit in this particular research method of data collection (Živković, 2015). At the same time, to talk about the feature of Jovan Cvijić as researchers, including first theoretical preparation for empirical research, to create a more active relationship between theory (as everything that previously known about the phenomenon that studies) and empirical - research into its operational phase. Accordingly, he has two associated properties, but they are distinct preference for empirical research, to discover new facts, checking the current scientific understanding and ability to establish each individual research on a theoretical basis.

"Guidelines for testing the origin population and psychological characteristics" consisting of three parts: (1) the position of villages and towns and their economy; (2) the origin of the population and countryside; (3) psychological features. When he observed the position of villages and towns and their economies, he included questions relating to the geographical and regional location of the village, the population, the type of economy, changes in the economy, migration caused by economic reasons, methods and changes in the way of building houses, building style, names of parts of houses, outbuildings, as well as questions about parts of the village or town. When it comes to the origin of population and the origin of the village, he indicates the different sources from which to obtain such data (old "reliable people", indigenous families). In this regard, he notes that attention should be paid to the layout of the houses and differences between natives and immigrants (according to various aspects, for example, by the type of glory, by language, customs, clothing, appearance, manners).

Exploring psychological features, he was particular interested in psychological features of villages or area, as well as changes that have occurred. The interesting part is the psychological characteristics of the rural population that 
is trying to find out through anecdotes, proverbs, short stories, different customs in daily life, relations of parents to children, kinship relationships, features that are characteristic of the region and its inhabitants. On this basis, he classified the psychological types of rural population.

When investigating the psychological characteristics of indigenous and immigrants, he highlighted that this research should be coordinated and harmonized with the examination of the origin of the population, where the emphasis was on the differences in appearance, dress and customs. In this way, at the same time, he has reviewed some characteristics and values of individual families who were detailed observed (for example, why some families are more or less appreciated, indicate the quiet, respectable family, those families that are its characteristics infirm, but they last). At the end, he made a remark that such tests most demanding scientific works because it is difficult to maintain objectivity and critical thinking and different perspectives or conditional generalization can also lead to an incorrect conclusion.

Guidelines by Jovan Cvijić are in some way a general framework which should connect and direct the work of many researchers and collaborators, but certainly not a template that could unleash their creative originality. At the beginning of the research he managed to establish a broad theoretical and problematic concept which guided this research and synthesized them. In anthropogeographic research, the social science methods are applied, such as:

- the method of direct observation;

- method of psychological and ethno-psychological profile;

- geographic and the comparative method;

- historical and genetic method;

- cartographic and graphical method;

- statistical methods and

- methods of systematization, classification and typology (Spasovski, Šantić, 2016).

Based on the success of the geographic study of genetic methods, Jovan Cvijic is worth pointing out that only this method, because it studies the evolution, explains the origin of forms, phenomena and processes. However, he stressed that it is not enough just to observe without a deeper contemplative work. We encounter historic-geographic approach when it comes to defining spatial extent of a research of Eastern Serbia in the anthropogeographic school of Jovan Cvijić, from which contemporary Serbian ethnology evolved together with ethnography (Knežević, Vojković, 2015). Therefore, the biggest attention is on the processes of ethnogenesis, ethno-evolution and ethno-transformation. These processes are studied on the basis of family, kinship and tribal traditions, migration flows from the mountains to the plains and on the basis of ethnic as- 
similation. He knew the chances ethnographic Balkan Peninsula and then political and historical events that influenced in this region formed a characteristic (complex) ethnic mosaic and stressed the need for making ethnographic map of the Balkan Peninsula (Lović-Obradović, Štrbac, 2017). In the study of anthropogeographical problems, conducted by their students and associates, in the first place required to explain the phenomena of national life and that explanations and conclusions are based on the data. He stated that to real scientific results can only come when you get out of the description and in the interpretation. It is also pointed out that scientific work has its own course and stages. This work begins adding and selecting materials, and then comes a higher level of scientific work that begins deep observations, which often contain an explanation of the facts and phenomena. With these observations are born hypotheses, often only a working hypothesis, such, according to which should be further examined.

His basic method is direct observation and observation of objects on the geographic area. According to Jovan Cvijić, atlas and maps for geographers are the lexicon for researcher, he must constantly see them, cross out and learn the topography and travel, the most powerful tool for geographic studies, it is worth the most. He is the first scientific researcher of our people, the first scientist who went in person to the people and direct observation and examination of the people, carried out the study and came to the scientific results. In the field, it is researched and collecting empirical data about the natural geographic environment, migration of the population, the origin population, settlements, material culture, psychological characteristics, tribes and families.

It is notable that in his scientific and research work presents a combination of several methods and that he is an experienced performer of geographical area. Jovan Cvijić left a useful conclusion for the contemporary field research. It happens that some researchers have clearly defined aims for which specific data collected and managed more interesting questions than those which serve the purpose of a specific investigation. In these shortcomings, researchers subsequently attempt to attach greater importance to the conclusions of the phenomena that have collected data and their disposal (Janković, Novakov, Petrović, 2017). In this sense, he emphasizes that basic, therefore, draws Guidelines and anthropogeographic work of his students examine the problems for them to gather material, does not material of which no one knows what it is. Each question in Guidelines has a specific task and does with all other unit, which has a tendency to take all sides anthropogeographic highlight problems so that they see the causes, causes various and complicated. This means that he is trying to apply the methodological principles on which it is necessary that, taking into account the relevant theoretical knowledge, parse the contents of the main aims of the research. With him, each individual question or problem has a clear role in achieving of the primary aim and research plan. 
The analysis of Cvijić's research methodology of social phenomena, reveals several important elements:

- the theoretical basis and preparing the research plan;

- avoid collecting those data that demand additional processing;

- overcoming description and pointing to the need for a scientific explanation of the cause detection.

The properly implementation of typological process and creating the complex types of different phenomena (villages, psychological types) was enabled by using collected material according to the Guidelines that is later processed in detail. His Guidelines for the study of the village was his basis for the creation of materials monographs of the observed villages. Data processing, the detection of the common, general and enduring properties of villages, psychological types, the migration current and cultural belts, Cvijić was created typology that play an important role in the understanding and determination of the fundamental inner relationship to the studied phenomena, as well as their relationships with other relevant social phenomena. Further theoretical elaboration of these types moved their role from descriptive to the applicative (Janković, Novakov, Petrović, 2017).

Jovan Cvijić has introduced another methodological concept, which represents an interdisciplinary approach created from the sets of coordinated theoretical concepts and methodologies of related sciences in order to investigate certain scientific problems. There are many ways in which research framework begins to expand and interdisciplinarity is one of them that investigating and solving a given problem, by using more than one scientific discipline (Živković, et al., 2017). Recognizing its importance, he combines knowledge of geography, demography, history, sociology, psychology, ethnology and economics, as well as other skills that could help in better explaining of the research subject.

\section{Conclusion}

Jovan Cvijic is one of the first scientists to research task understood as objectively, accurately and systematically creating a record of the phenomena and processes that had not been studied enough. His contribution consists in creating a research tradition that is the basis for the subsequent geographical research. He has published five detailed guidelines for field research of population and settlements to direct scientific work of his young associates. Its methodological guidelines are important for today's field research, but require adaptation to new concepts of modern science. Numerous trips with the participation of his contribution to notice differences in the ethnic sense, distribution of ancient cul- 
tures, the degree of enlightenment of the people, the level of economic development, type and location of the settlement, the type and appearance of the house. On trips directly acquainted with the living conditions of the population of the Balkan Peninsula, which developed his desire to deal with ethnographic, political and ethnographic and later psycho-social questions.

Eminent scientist was characterized by its directness with nature and people. He received the information, interesting and actuality so as to specific locations in Serbia sent a team of young scientists and personally went to record changes or discovered new geographical areas that are not due to inaccessibility explored. Throughout his life he dedicated field investigations and he was ready to transfer his knowledge to new generations of Serbian scientists. It was written a lot about him as an exceptional university educator of many generations during life.

\section{Acknowledgments}

This paper presents results of the research project number 176008, funded by the Ministry of education, science and technological development of Republic of Serbia.

\section{References}

Živković, Lj. (2015). Terenski rad i ekskurzije u nastavi geografije. Beograd: Srpsko geografsko društvo.

Živković, Lj., Jovanović, S., Đorđević, I., \& Golubović, N. (2017). Interdisciplinaran pristup nastavnim sadržajima geografije u osnovnoj školi. Glasnik Srpskog geografskog društva, 97(1), 137-158.

Janković, D., Novakov, M., \& Petrović, M. (2017). Iskustva empirijskih istraživanja u ruralnim područjima: izazovi intervjua i ankete. Agroekonomika, 46-74.

Knežević, A., \& Vojković, G. (2015). Spatial extent in demographic research approach and problems. Bulletin of the Serbian Geographical Society, XCVI(2), 1-24.

Lović-Obradović, S., \& Štrbac, D. (2017). Principi i metode za izradu etnografske karte Balkanskog poluostrva. U: Milovanović-Pešić, A. (ur.) Iz beležnica Jovana Cvijića - prikazi i tumačenja. Posebna izdanja, knj. 94, 112-113.

Prelić, M. (2014). Jovan Cvijić i prve decenije formiranja i institucionalizovanje etnologije kao nauke u Srbiji. Glasnik Etnografskog Instituta, 62(2), 83-96.

Spasovski, M., \& Šantić, D. (2016). Reaffirmation of the population origin studies in Serbia in early $21^{\text {st }}$ century. In: Jović, V., Petrović, A. (eds.) $150^{\text {th }}$ Anniversary of Jovac Cvijić birth. Proceedings of the International Conference held at the Serbian Academy of Sciences and Arts, October 12-14, 2015, CLXII(1), 603-613. 
Stanković, S. (2016). Jovan Cvijić and the Serbian Geographical Society. In: Jović, V., Petrović, A. (eds.) $150^{\text {th }}$ Anniversary of Jovac Cvijić birth. Proceedings of the International Conference held at the Serbian Academy of Sciences and Arts, October 12-14, 2015, CLXII(1), 45-59.

Šabić, D., Pavlović, M., \& Vujadinović, S. (2016). Geographical research of isolation and separation features of the Balkans in the time of Cvijić and today. In: Jović, V., Petrović, A. (eds.) $150^{\text {th }}$ Anniversary of Jovac Cvijić birth. Proceedings of the International Conference held at the Serbian Academy of Sciences and Arts, October 12-14, 2015, CLXII(1), 767-777. 